\title{
Detection of SARS-CoV-2 virus using acute respiratory infections sentinel surveillance system (PIDIRAC) in Catalonia (Spain)
}

Mireia Jané ( $\nabla$ mireia.jane@gencat.cat )

Agència de Salut Pública de Catalunya

Ana Martínez

Agència de Salut Pública de Catalunya

Pilar Ciruela

Agència de Salut Pública de Catalunya

Mar Mosquera

Hospital Clinic of Barcelona

Miquel Martínez

Hospital Clinic of Barcelona

Luca Basile

Agència de Salut Pública de Catalunya

$M^{2}$ José Vidal

Agència de Salut Pública de Catalunya

$M^{\mathrm{a}}$ Mercè Noguera

Agència de Salut Pública de Catalunya

Patricia de Molina

Hospital Clinic of Barcelona

Jordi Vila

Hospital Clinic of Barcelona

$M^{a}$ Angeles Marcos

Hospital Clinic of Barcelona

\section{Research Article}

Keywords: SARS-CoV-2, COVID-19, PIDIRAC, Catalonia

Posted Date: December 2nd, 2020

DOl: https://doi.org/10.21203/rs.3.rs-109617/v1 
License: (c) (i) This work is licensed under a Creative Commons Attribution 4.0 International License. Read Full License 


\section{Abstract}

In the context of the Covid-19 pandemic in Catalonia (Spain), the first SARS-CoV-2 case confirmed was notified to the Catalonia Epidemiological Surveillance Network (RVEC) on 25 February 2020. The present study describes and analyses the respiratory samples obtained in primary care using PIDIRAC epidemiological sentinel surveillance system to complement the pandemic surveillance system activated, and describe whether SARS-CoV-2 was circulating before the first case detected in Catalonia, between October 2019 and April 2020.

During this period, 878 respiratory samples from patients with acute respiratory infection or influenza syndrome obtained by PIDIRAC epidemiological sentinel surveillance system were analysed. Of the total sample, $51.9 \%$ tested positive to influenza virus and $48.1 \%$ to other respiratory viruses, with SARS-CoV-2 being present in 6 samples. The first SARS-CoV-2 positive case showed the first symptoms on 2 March 2020. These were 3 men and 3 women aged between 25 and 50 years old (mean age 44.5 years old). Fever, general discomfort, coughing, chills, and arthromyalgia were the most frequent symptoms in the SARS-CoV-2 cases.

Likewise, 44 samples that had tested positive for coronavirus during 2018-2019 were typed. They were all typed as one of the regular CoV, none of them being SARS-CoV-2.

The acute respiratory infections sentinel surveillance system (PIDIRAC) reinforces the global epidemiological surveillance, allows to corroborate whether there is virus circulation or not, and helps confirm that generalised community transmission in Catalonia took place in mid-March.

\section{Introduction}

On 31 December 2019, the Wuhan Municipal Health Commission in the Province of Hubei, China, announced a cluster of 27 cases of pneumonia of unknown aetiology, including 7 severe cases, with common exposure taking place in a wholesale market of seafood, fish and live animals in the city of Wuhan, without identifying the outbreak source $\left({ }^{1}\right)$. The market was shut down on 1 January 2020. On 7 January 2020, Chinese authorities identified a novel type of virus from the Coronaviridae family as the causative agent of the outbreak, which was called coronavirus SARS-CoV-2 $\left({ }^{2}\right)$. The Chinese authorities shared its genetic sequence on 12 January 2020. On 30 January 2020, the World Health Organization declared the outbreak of coronavirus SARS-CoV-2 a public health emergency of international concern in China $\left({ }^{3}\right)$. Afterwards, the outbreak spread beyond China, affecting other countries, many of them in Europe. In February, the number of cases started to fall in China as it increased in other countries, especially in Europe $\left({ }^{4}\right)$.

Reported cases increased dramatically and spread exponentially around the world. On 11 March 2020, WHO declared the infection of SARS-CoV-2 a pandemic $\left({ }^{5}\right)$. The outbreak in Italy affected a large number 
of cases, and from there, the cases spread to Spain. In Catalonia as to 27 May 2020, the number of confirmed cases was 58,480 people $\left({ }^{6}\right)$.

The first confirmed case of SARS-CoV-2 in Catalonia was notified on 25 February 2020 to the Catalonia Epidemiological Surveillance Network (RVEC). It was a 36-year old Barcelona female resident who had travelled from 12 to 22 February to the cities of Bergamo and Milano. Symptoms appeared on 20 February; she required hospitalization and evolved positively.

Cases increased slowly in Catalonia during the containment stage -first stage of the pandemic- as RVEC strictly applied the action protocol for cases of infection with the new coronavirus SARS-CoV-2 drawn up by the Sub-directorate General for Surveillance and Public Health Emergency Response $\left({ }^{7}\right)$-agreed upon as part of the State Epidemiological Surveillance Network (RENAVE)- and by the Coordination Centre for Sanitary Alerts and Emergencies (CCAES) ${ }^{8}$ ). A screening system was specifically established by the RVEC and the Catalonia Epidemiological Surveillance Emergency Service (SUVEC) with the information provided by health care centres and the laboratory network from both the public and private health care sector. This is an active surveillance of cases and contacts to establish the necessary tests and implement isolation and quarantine required, which implied the restriction of movement of the cases' close contacts. This was a pioneering measure as Catalonia kept a limited transmission of the located chains for some time before reaching community transmission and helped limit transmission until the mitigation stage with generalised community transmission on 14 March 2020.

In addition to the active surveillance system established as a response to the health alert, Catalonia has implemented a surveillance system for influenza and other acute respiratory infections (PIDIRAC) since the 1999-2000 season. It is based on a surveillance network with 56 primary care physicians, family physicians and paediatricians who work in 44 primary care health care centres homogenously distributed, covering around $1 \%$ of Catalonia population. The PIDIRAC system is part of the national influenza surveillance system. For many years $\left({ }^{9},{ }^{10}\right)$, it has been supported by several systems and information sources from different territories around the country, being also part of the European Influenza Surveillance Network (EISN) which is coordinated by the European Centre for Disease Control (ECDC) since 2008, contributing in this way to the overall objectives in terms of influenza international surveillance. The EISN also encompases several laboratories that are part of the European Reference Laboratory Network for Human Influenza (ERLI-Net).

The objective of this study is to describe and analyse the respiratory samples obtained in primary care as part of the epidemiological sentinel surveillance system PIDIRAC, to complement the active surveillance system implemented in the pandemic and establish whether SARS-CoV-2 was circulating before the first case was detected in Catalonia, between October 2019 and April 2020.

\section{Methodology}

\section{Surveillance system}


In January 2020, Catalonia deployed a reinforced surveillance system in the light of the public health emergency of international concern, in collaboration with RENAVE and CCAES. During the containment stage, and following WHO guidelines, the clinical and epidemiological criteria of the Action protocol for cases of infection of the new coronavirus SARS-CoV-2 (7) was implemented. Clinical and epidemiological criteria changed with the evolution of the infection and the pandemic stage. Once the first local cases emerged in Italy on 21 February $2020\left({ }^{11}\right)$, a case under investigation was considered to be any individual with a clinical picture compatible with acute respiratory infection of sudden onset and some of the following symptoms: coughing, fever, dyspnoea regardless of its severity and who, in the 14 days prior to symptoms onset, met any of the following epidemiological criteria: travel history to areas with evidence of community transmission such as China (all provinces, including Hong Kong and Macao), South Korea, Iran, Japan, Singapore and Italy (regions such as Lombardy, Veneto, Emilia-Romagna, Piedmont). Cases under investigation were RT-PCR tested for SARS-CoV-2 using nasopharyngeal swabs.

Additionally, other cases outside these areas, exposure to events with a cluster of cases or with transmission chains of significant size as well as with a history of close contact with a possible or confirmed case were also researched.

Also, PIDIRAC continued its activity with professionals who collected pharyngeal and nasal samples during October 2019-March 2020 surveillance season. Besides influenza A, B, and C virus, other virus under study include respiratory syncytial virus, parainfluenza virus, adenovirus, coronavirus, enterovirus, rhinovirus, metapneumovirus and bocavirus.

Sentinel physicians notify the cases or cluster of cases that are highly likely to have respiratory infection and collect respiratory samples that are sent for diagnosis to Hospital Clínic de Barcelona laboratory, a reference laboratory for respiratory virus in Catalonia.

\section{Microbiology}

All the samples collected as part of PIDIRAC sentinel surveillance were part of a prospective study on influenza $A, B$ and $C$ virus, adenovirus, respiratory syncytial virus, bocavirus, metapneumovirus, parainfluenza virus, rhinovirus, enterovirus and coronavirus (CoV) using a multiple Reverse Transcriptase PCR (RT-PCR) in real time.

The respiratory virus were analysed with a semiautomated platform (Flow system, Roche Diagnostics $\mathrm{GmbH}$, Mannheim, Germany) that includes nucleic acids extraction with MagnaPure and amplification and detection of the virus using thermocycling LightCycler 480. Specific primers and probes were used for the above mentioned virus (LightMix ${ }^{\circledR}$ Modular, TIB MOLBIOL, GmbH, Berlin, Germany). All positive samples for coronavirus were subsequently typed for HKU1, OC43, NL63, 229E. Every respiratory sample was frozen at $-80^{\circ} \mathrm{C}$ and retrospectively studied for the presence of SARS-CoV-2 with the cobas SARSCoV-2 assay on the 6800 platform (Roche Diagnostics). The cobas assay amplify and detect two viral targets: ORF1 $\mathrm{a} / \mathrm{b}$, a non-structural region that is unique to SARS-CoV-2 and a conserved region in the Egene, which is a structural protein envelope for pan-Sarbecovirus detection. 


\section{Statistical analysis}

For each case, the following variables were analysed: age, sex, municipality, date of case diagnosis and notification, clinical picture, risk factors, hospitalization, ICU admission, travel history, close contact of COVID19 and whether it was a health care professional. A descriptive study has been done and the presence of significant differences in these variables between SARS-CoV-2 cases and the rest of coronaviruses has been analysed in a bivariate study with Chi2 test, with statistical significance at $95 \%$.

\section{Ethical considerations}

All data used in the analysis were collected during routine public health surveillance activities, as part of the legislated mandate of the Health Department of Catalonia, the competent authority for the surveillance of communicable diseases, which is officially authorized to receive, treat and temporarily store personal data on cases of infectious disease. Therefore, all study activities formed part of public surveillance and were thus exempt from institutional board review and did not require informed consent. All data were fully anonymized.

\section{Results}

From 1 October 2019 to 1 April 2020, a total of 878 sentinel respiratory specimens from patients presenting influenza-like illness (ILI) or acute respiratory infection (ARI) symptoms were analysed as part of the PIDIRAC Program. From the total sample, 69.7\% (612) tested positive to respiratory virus, with a total of 691 viral isolations. Figure 1 shows the circulating virus during the season under study. Among respiratory virus, $51.9 \%$ were positive to influenza virus and $48.1 \%$ to other respiratory virus from which $5.1 \%$ (35) were CoV. Virus distribution is shown in Table 1.

The $35 \mathrm{CoV}$ virus were typed as follows: $18 \mathrm{NL} 63,5 \mathrm{HKU1}, 5$ OC43, 1 as 229E while the remaining 6 were not typed. In the retrospective study of SARS-CoV-2, only 6 out of the 878 samples tested positive, coinciding with the 6 untyped samples positive to coronavirus. These $6 \mathrm{CoV}$ tested positive to SARS-CoV2 in the subsequent tests.

The first SARS-CoV-2 positive case showed the first symptoms on 2 March 2020 and the last one on 16 March 2020 while in cases positive to other CoV, symptom onset started between 20 October 2019 and 7 March 2020. In 4 cases (66.7\%), patients with SARS-CoV-2 showed a sudden onset of symptoms while 12 patients $(41.4 \%)$ affected by other coronavirus had a sudden debut. Fever and dyspnoea were more frequent in the SARS-CoV-2 cases ( $100 \%$ and $33.3 \%$, respectively) compared to other CoV $(72.4 \%$ and $6.9 \%$, respectively), although without significant differences between the two groups. Symptoms shown are included in Table 2.

SARS-CoV-2 patients were 3 men and 3 women, aged 25 to 50 years old with mean age of 44.5 years old, residents of sanitary regions of Girona (4 cases), Catalunya Central (1 case) and Barcelona Sud (1 case). 
People identified as positive to other CoV were 17 women (58.6\%) and 12 men (41.4\%) aged 1 to 87 years old.

Cases caused by other CoV infections (29 cases) were distributed as follows: 6 Barcelonès Nord, 3 Barcelonès Sud, 4 Barcelona city, 4 Catalunya Central, 8 in Tarragona, 1 in Girona, 1 Terres de l'Ebre, 1 in Lleida and 1 in Alt Pirineu-Aran.

In 4 cases (66.6\%) SARS-CoV-2 patients suffered some underlying pathology that implied an increased risk of infection while in the other CoV cases, only 12 patients (41.4\%) presented risk factors.

None of the SARS-CoV-2 cases suffered from coinfection with the virus under study, while 8 of other CoV (27.6\%) were coinfected with other respiratory virus: 2 with rhinovirus (HRV), 2 with respiratory syncytial virus (HRSV), 1 with influenza virus (FlubV), 1 bocavirus (HBoV), 1 adenovirus (HAdv) and 1 virus parainfluenza-2 (HPIV-2).

None of the SARS-CoV-2 cases had been in contact with a possible case of influenza or SARS-CoV-2 nor did they have travel history to areas with community transmission at that moment. One of the SARS-CoV2 cases was a health care professional.

All patients evolved favourably. None of the cases affected with non-SARS CoV required hospitalization. One of the cases with SARS-CoV-2, with previous respiratory pathology, required hospitalization and evolved favourably.

Likewise, the 44 samples positive to coronavirus during the 2018-2019 season were typed. They all typed to some of the regular CoV (229E, HKU1, NL63 and OC43) none of them being SARS-CoV-2.

\section{Discussion}

In the case of a pandemic like SARS-CoV-2, considering different epidemiological surveillance systems is essential to reinforce monitoring and early detection of circulating cases as much as possible in order to implement different public health actions depending on the required stage.

In Catalonia, the first Covid-19 case was detected on 25 February. From that moment until mid-March, transmission chains of the virus were perfectly located during the containment stage and cases were immediately studied and followed-up to contain the disease (7). The PIDIRAC system, functioning since October 2019, corroborated that although the regular seasonal coronavirus was already circulating, SARS-CoV-2 community presence started at the beginning of March, which indicated that transmission increased from that moment onwards. Likewise, this study allows to conclude that the PIDIRAC system did not detect any case prior to the first RVEC notification.

The first six SARS-CoV-2 cases reported through the PIDIRAC sentinel network were mild cases detected during the containment stage, after the first SARS-CoV-2 case was detected by RVEC. 
Despite the absence of significant differences between SARS-Cov2 and the other CoV, SARS-Cov-2 mainly affects adults with risk factors while CoV affected almost all age groups and, to a lesser degree, patients with risk factors. None of the SARS-Cov-2 cases presented coinfection with other respiratory virus under study unlike CoV cases which presented coinfection with other different respiratory virus (almost one third of the cases). Similarly, Gaunt ER et al in UK describe coinfection between CoV and RSV, influenza and adenovirus between 11 and $41 \%\left({ }^{12}\right)$.

Following WHO recommendations, both surveillance systems - sentinel and pandemic containment systems- coexisted in Catalonia. Likewise, European countries progressively implemented a strong surveillance of COVID-19 cases to draw a global strategy to contain COVID-19, which was progressively complemented with different epidemiological surveillance systems $\left(3,{ }^{13}\right)$. The sentinel surveillance systems are recommended by the European surveillance network, especially in European regions or states where mild cases were not tested at the beginning, as it is our case $\left({ }^{14}\right)$.

France was the European country where the first three cases were diagnosed on 24 January. These were people with travel history to Wuhan $\left({ }^{15}\right)$. Likewise, their acute respiratory infections sentinel surveillance system showed that several nasopharyngeal swabs tested positive to SARS-CoV-2. Excess cases due to acute respiratory infection was quantified in France at the beginning of March compared to the number of visits expected from the seasonal influenza virus epidemic $\left({ }^{16}\right)$.

Regarding the study limitations, it is worth noting that the respiratory clinical portrait of the influenza in the context of the PIDIRAC Program could not allow for identifying a COVID-19 possible case, either because symptoms were very mild and the person did not visit the physician or because it was an asymptomatic COVID-19 case. The presence of pathogens others than SARS-CoV-2 does not guarantee that a patient was not SARS-CoV-2 positive $\left({ }^{17}\right)$. However, our study did not show any coinfection with other virus. Fabiona Gámbaro et al demonstrates that the virus had been previously circulating in France, with the additional challenge of asymptomatic cases $\left({ }^{18}\right)$. Similarly, as the sentinel surveillance system is focused on community, it would have not detected severe influenza syndrome cases that would have been hospitalised prior to the announcement of the international public health emergency at the end of January. However, we corroborated that the other regular epidemiological surveillance systems, i.e. the compulsory declaration diseases system (MDO) and Catalonia microbiological notifications system (SNMC), did not detect any case before 25 February.

The acute respiratory infections sentinel surveillance system, PIDIRAC, reinforces the global epidemiological surveillance, allows for confirming whether the virus is circulating or not, and helps verify that generalised community transmission in Catalonia took place in mid-March. Public Health departments should rely on sentinel systems to determine SARS-CoV-2 community transmission levels and thus prioritise community mitigation measures $\left({ }^{19}\right)$. Marissa $L$ et al gathers that COVID-19 case identification through a sentinel surveillance system helps confirm SARS-CoV-2 community transmission and that the implementation of early community measures is key for much effective mitigation of SARS- 
CoV-2 transmission $\left(20,{ }^{21}\right)$. As we approached generalised SARS-CoV-2 circulation, surveillance based on clinical criteria and sample collection by sentinel physicians was essential to assess the situation $\left({ }^{22}\right)$. PIDIRAC sentinel system is useful for monitoring SARS-CoV-2 community transmission and geographic expansion as well as being alert and prepared in the case of a potential emergency that may arise from a virus onset with pandemic potential, as that of influenza, while the COVID-19 pandemic remains active $(23)$.

\section{Declarations}

\section{Acknowledgements}

Acute respiratory infections sentinel surveillance system (PIDIRAC): Juan Azemar Mallard (CAP Roquetes, Sant Pere de Ribes) , Dolors Basas Prats (ABS Vilanova del Camí, Vilanova del Camí) Pilar Biendicho Palau (ABS Balaguer, Balaguer) Maria Boldu Franque,(EAP Lleida 4(Balafia Pardinyes, Lleida) Montserrat Bonet Porqueras,(EAP Seu d'Urgell, La Seu d'Urgell) Albert Brau Tarrida,(EAP Sant Adrià del Besos-2, LA MINA) Ma Pilar Broto Escapa , (ABS Badalona 6 Llefia, Badalona) Montserrat Callado Coma, ( ABS Barcelona-8 Roqueters, Barcelona) Rosa $M^{a}$ Campobadal Molina, ABS Vilanova del Camí, Vilanova del Camí) Sergi Campos Fajardo (ABS OLOT , OLOT) Montserrat Cañas Nebrera, (EAP Gava-2, GAVA) Emili Ciurana Roca, (ABS Tortosa, Tortosa) Jose Ma Cots Yago, ( EAP Barcelona La Marina, Barcelona)David De La Rica Escuin, (ABS Artesa de Segre, Artesa de Segre) Guillermo Elizalde Del, Rio, (ABSA Montblanc, Montblanc) laura Estrella Sanchez, (Cap Montcada i Reixac, Montcada i Reixac) Olga Fernandez Fernandez,(EAP Montornès, Montmeló) Josep Ferran Ferran ABS Barcelona Roquetes, (Barcelona)Emili Fos Escrivà,(Penedès Rural ,Vilafranca del Penedès) Gloria Gadea Borguño, (EAP BCN Para Claret, Barcelona) Raquel Garcia Garcia (EAP Montornès , Montmeló)Carles Gatius Tonda,(EAP Lleida-3 I'Eixample, Lleida) Ma Jesus Gelado Ferrero,( ABS Celrà, Celrà) Paula Gomez Iparraguirre( EAP La Serra Sabadell) Ma Merce Grau Fernandez(EAP Sant Quirze del Vallès, Sant Quirze del Vallès) Montserrat Grivé Isern,(Cap Tarraco, Tarragona) Paola Micaela Gutierrez Ardaya, (ABS Mataró Ronda Gatassa, Mataró) Mari Cruz Bonilla Guzman, (ABS La Salut, Badalona) Rosario Hernandez Ibañez,(EAP BCN La Marina ,Barcelona) Liliana Kristensen Alvarez, (Cap Moncada i Reixac, Montcada i Reixac) Ana Maria Llusa Parramon (ABS La Pobla de segur, La Poble de Segur) Cristina Lopez Mompo, (ABS Sta. Coloma de Gramenet Santa Coloma de Gramenet) Lucia Losada Pavón, (ABS BCN Drassanes, Barcelona) M .Esperanza Macia Rieradevall,(ABS Manlleu. Manlleu) Emili Marco Segarra, (ABS Sarrià de Ter, Sarrià de Ter)Montserrat Marta Marti Garcia,(Cap Dr. Ribas, Barcelona) Mercedes Martinez Fernandez, (ABS BCN Roquetes, Barcelona) Karina del Valle Marulanda Vargas,(ABS Mora la Nova, Mora la Nova) Xavier Moncosi De Borbon , (ABS Roses, Roses) Angels Naranjo Orihuela,(ABS Montblanc, Montblanc) $M^{a}$ Eugenia Ortola Castells, (Cap BCN Pare Claret, Barcelona)Francesc Paris Palleja, (Reus -3 Reus) Ma Mar Perez Cifuentes , BCN Pare Claret, Barcelona) Cristina Pozo Díez, (BCN EAP Numancia, Barcelona) Ramon Pujol Martinez, (EAP TREMP, Tremp) Alexandra Reguart Aransay, (Cap Alcarràs, Alcarràs) Anna Maria Ribatallada Díez (ABS Cerdanyola, Cerdanyola) Nuria Sarra Manetes, (Tarragona -1 La canonja, (Tarragona) Eduard Tarrago Sala( L'Hospitalet Cap Bellvitge, Bellvitge)Elena Valén Suñer, ABS Manresa 
Sagrada Família, Manresa)Ivan Valencia Pedraza ,(ABS L'H Sta. Eulalia L'Hospitalet Llobregat) Cornelis Van Tartwijk, (BCN Gòtic, Barcelona) Renee Vink SCHOENHOLZER,(Cap Manlleu, Manlleu) Eduardo Zabala Charramendi, (ABS Reus).

\section{Author contributions}

All the authors have been directly involved in the article untitled: Detection of SARS-CoV-2 virus using acute respiratory infections sentinel surveillance system (PIDIRAC) in Catalonia (Spain). In addition, all of them have substantially contributed in all the necessary information described in the manuscript, from the conception and design, the acquisition and data processing, the analysis and its interpretation.

Mireia Jané, Ana Martínez and Pilar Ciruela have contributed in the design and writing of the manuscript as well as in the coordination of the Pidirac sentinel surveillance system. Maria José Vidal has contributed in the bibliography revision and the technical support of the investigation. Luca Basile and $M^{a}$ Mercè Nogueras have contributed in the statistical analysis of data. Mar Mosquera, Miquel Martínez, Patricia de Molina, Jordi Vila, and $\mathrm{M}^{\mathrm{a}}$ Angeles Marcos have carried out the microbiological analysis of all the samples collected as part of PIDIRAC sentinel surveillance System for both years.

All authors have contributed in a critical revision of the contents.

Compliance with Ethical Statements

Conflicts of interest

The author declares that neither they nor any of the co-authors have a conflict of interest regarding the publication of this manuscript.

\section{Ethical approval:}

This article does not contain any studies with human participants or animals performed by any of the authors.

\section{Ethical considerations}

All data used in the analysis were collected as part of routine public healthsurveillance activities and were therefore exempt from institutional review board review.

\section{References}

1. European Centre for Disease Prevention and Control. Cluster of pneumonia cases caused by a novel coronavirus, Wuhan, China; - 17 January 2020. ECDC: Stockholm; 2020.

2. European Centre for Disease Prevention and Control. Outbreak of severe acute respiratory syndrome coronavirus 2 (SARS-CoV-2): increased transmission beyond China - fourth update, 14 February 2020. ECDC: Stockholm; 2020. 
3. European Centre for Disease Prevention and Control. Outbreak of acute respiratory syndrome associated with a novel coronavirus, China: first local transmission in the EU/EEA - third update. 31 January 2020. ECDC: Stockholm; 2020.

4. World Health Organization. (2020). Critical preparedness, readiness and response actions for COVID19: interim guidance, 7 March 2020.

5. European Centre for Disease Prevention and Control. Novel coronavirus disease 2019 (COVID-19) pandemic: increased transmission in the EU/EEA and the UK - sixth update - 12 March 2020. Stockholm: ECDC; 2020.

6. Informe tècnic de resum dels casos de la COVID-19 a Catalunya. Número 12. [Technical summary report of COVID-19 cases in Catalonia. Number 12] Sub-direcció General de Vigilància i Resposta a Emergències de Salut Pública. Departament de Salut. [Deputy director of public health surveillance and response to emergencies. Department of Health]

7. Procediment d'actuació enfront de casos d'infecció pel nou coronavirus SARS-CoV-2.Sub-direcció General de Vigilància i Resposta a Emergències en Salut Pública. Departament de Salut. [Deputy director of public health surveillance and response to emergencies. Department of Health]

8. Procedimiento de actuación frente a casos de infección por el nuevo coronavirus (SARS-CoV-2). [Action protocol for infection cases by the novel coronavirus (SARS-CoV-2)] Centro de Coordinación de Alertas y Emergencias Sanitarias. Ministerio Sanidad. [Coordination Centre for Sanitary Alerts and Emergencies. Ministry of Health]

9. Pla d'informació de les infeccions respiratòries agudes a Catalunya (PIDIRAC) 2019-2020. [Information Plan on acute respiratory diseases in Catalonia (PIDIRAC) 2019-2020] Sub-direcció General de Vigilància i Resposta a Emergències en Salut Pública. Departament de Salut. [Deputy director of public health surveillance and response to emergencies. Department of Health]

10. [1]:Sistema de Vigilancia de la Gripe en España [Spanish Influenza Surveillance System] Available at: https://vgripe.isciii.es/inicio.do;jsessionid=0B3EE143B7F54A3A22B96759357097B2

11. Ciro Indolfi and Carmen Spaccarotella. The Outbreak of COVID-19 in Italy. Fighting the pandemic. JACC: Case Reports. April 2020. DOI.org/10.1016/j.jaccas.2020.03.012

12. E. R. Gaunt, A. Hardie, E. C. J. Claas, P. Simmonds, and K. E. Templeton. Epidemiology and Clinical Presentations of the Four Human Coronaviruses 229E, HKU1, NL63, and OC43 Detected over 3 Years Using a Novel Multiplex Real-Time PCR Method. J Clin Microbiol. 2010; 48(8): 2940-2947. DOI: $10.1128 / J C M .00636-10$

13. World Health Organization. Novel coronavirus (2019-nCoV). Situation report11.https://www.who.int/docs/default-source/coronaviruse/situation-reports/20200131-sitrep-11ncov.pdf?sfvrsn=de7c0f7_4

14. European Centre for Disease Prevention and Control. Strategies for the surveillance of COVID-19. Stockholm: ECDC; 2020

15. Bernard Stoecklin S, Rolland P, Silue Y, Mailles A, Campese C, Simondon A et al. First cases of coronavirus disease 2019 (COVID-19) in France: surveillance, investigations and control measures, 
January 2020. Euro Surveill. 2020; 25(6). DOI: doi.org/10.2807/1560-7917.ES.2020.25.6.2000094

16. Boëlle Pierre-Yves, Souty Cécile, Launay Titouan, Guerrisi Caroline, Turbelin Clément, Behillil Sylvie, et al. Excess cases of influenza-like illnesses synchronous with coronavirus disease (COVID-19) epidemic, France, March 2020. Euro Surveill. 2020 Apr;25(14):2000326. DOI: 10.2807/15607917.ES.2020.25.14.2000326.

17. European Centre for Disease Prevention and Control. Disease background of COVID-19. https://www.ecdc.europa.eu/en/covid-19/latest-evidence

18. Fabiana Gámbaro, Sylvie Behillil, Artem Baidaliuk, Flora Donati, Mélanie Albert, Andreea Alexandru et al. Introductions and early spread of SARS-CoV-2 in France. BioRXiv. April, 2020. DOI: https://doi.org/10.1101/2020.04.24.059576

19. Zwald ML, Lin W, Sondermeyer Cooksey GL, et al. Rapid Sentinel Surveillance for COVID-19- Santa Clara County, California. March 2020. MMWR Morb Mortal Wkly Rep 2020; 69:419-421. DOI: http://dx.doi.org/10.15585/mmwr.mm6914e3

20. Marissa L. Zwald, Wen Lin, Gail L. Sondermeyer Cooksey, Charles Weiss, Angela Suarez, Marc Fischer, et al. Rapid Sentinel Surveillance for COVID-19 - Santa Clara County, California, March 2020. US Department of Health and Human Services/Centers for Disease Control and Prevention. MMWR. April 10, 2020; 69 (14).

21. Qualls N, Levitt A, Kanade N, et al.; CDC Community Mitigation Guidelines Work Group. Community mitigation guidelines to prevent pandemic influenza-United States, 2017.MMWR Recomm Rep 2017; 66 (1). DOI: 10.15585/mmwr.rr6601a1

22. Spiteri G, Fielding J, Diercke M, Campese C, Enouf V, Gaymard A, et al. First cases of coronavirus disease 2019 (COVID-19) in the WHO European Region, 24 January to 21 February 2020. Euro Surveill. 2020 Mar;25(9). DOI: 10.2807/1560-7917.ES.2020.25.9.2000178

23. World Health Organization. Preparing GISRS for the upcoming influenza seasons during the COVID19 pandemic - practical considerations. Interim guidance. May 2020.

\section{Tables}

Table 1. Results of isolation due to virus. Samples from PIDIRAC sentinel network. 2019-2020 season 


\begin{tabular}{|lll|}
\hline Virology results & \multicolumn{2}{l|}{ Total Season } \\
\cline { 2 - 3 } & $\mathbf{N}$ & $\%$ \\
\hline Influenza Virus & 359 & $51.9 \%$ \\
\hline VGA & 163 & $23.6 \%$ \\
\hline A(H1N1)pdm09 & 94 & $13.6 \%$ \\
\hline A(H3N2) & 58 & $8.4 \%$ \\
\hline A no subtipat & 11 & $1.6 \%$ \\
\hline VGB & 194 & $28.1 \%$ \\
\hline VGC & 2 & $0.3 \%$ \\
\hline Other virus & 332 & $48.1 \%$ \\
\hline Rhinovirus & 107 & $15.5 \%$ \\
\hline Adenovirus & 50 & $7.2 \%$ \\
\hline Respiratory syncytial virus & 48 & $6.9 \%$ \\
\hline Coronavirus & 35 & $5.1 \%$ \\
\hline Parainfluenza virus & 29 & $4.2 \%$ \\
\hline Bocavirus & 29 & $4.2 \%$ \\
\hline Metapneumovirus & 17 & $2.5 \%$ \\
\hline Enterovirus & 17 & $2.5 \%$ \\
\hline Total isolations & 691 & $100.0 \%$ \\
\hline
\end{tabular}

Table 2. Clinical and epidemiological characteristics of Sars-CoV-2 and other CoV. Catalonia, October 2019-April 2020 


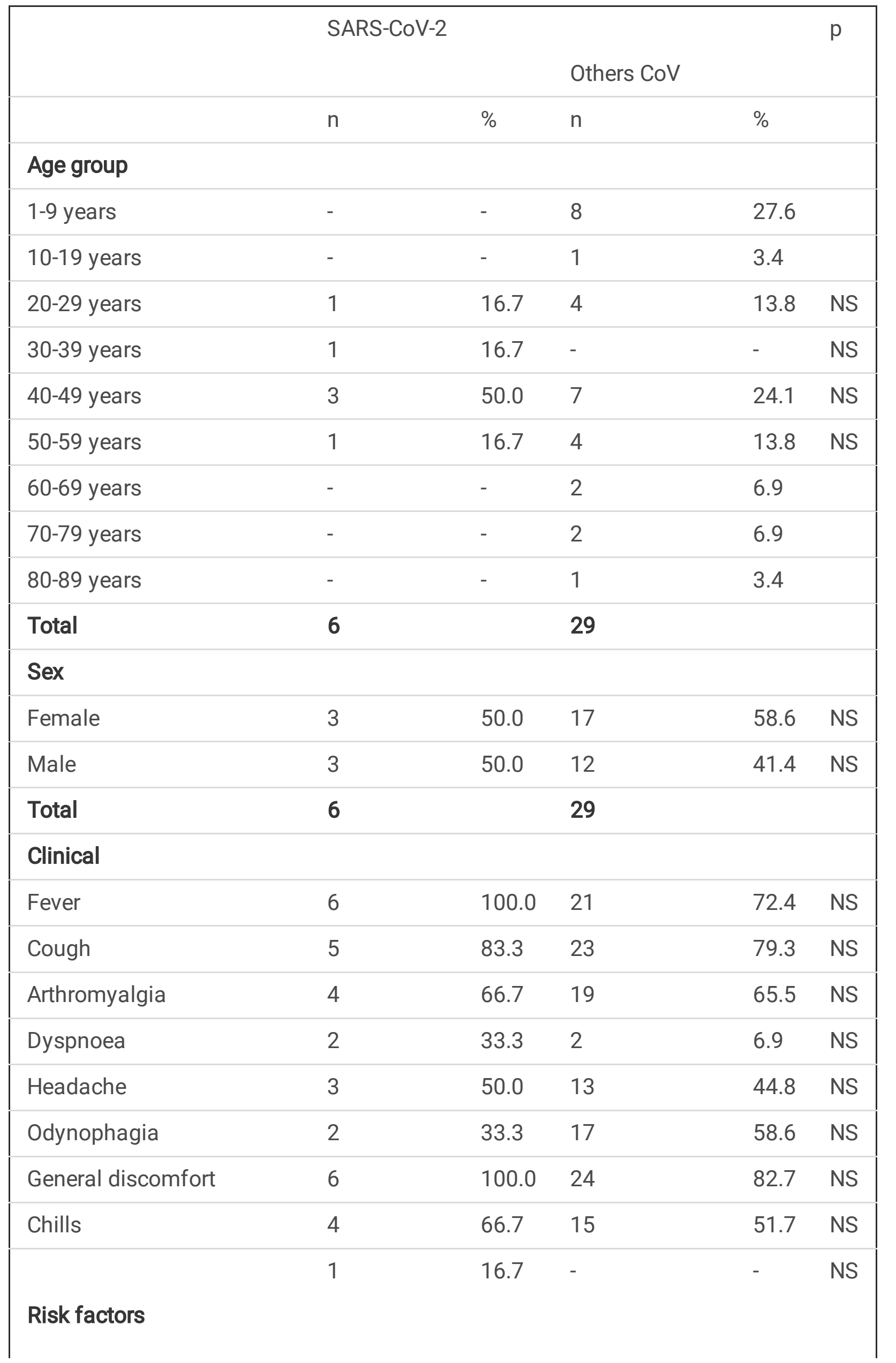




\begin{tabular}{|c|c|c|c|c|c|}
\hline Chronic respiratory disease & 2 & 33.3 & 6 & 20.7 & NS \\
\hline Cardiovascular disease & - & - & 2 & 6.9 & \\
\hline Obesity & 1 & 16.7 & 1 & 3.4 & NS \\
\hline Metabolic disease & - & - & 3 & 10.3 & \\
\hline Total & 4 & 66.6 & 12 & 41.4 & NS \\
\hline \multicolumn{6}{|l|}{ Hospitalization } \\
\hline Yes & 1 & 16.7 & - & - & NS \\
\hline \multicolumn{6}{|l|}{ ICU admission } \\
\hline Yes & - & - & - & - & \\
\hline \multicolumn{6}{|l|}{ Death } \\
\hline Yes & - & - & - & - & \\
\hline \multicolumn{6}{|l|}{ Coinfection } \\
\hline Yes & 0 & 0.0 & 8 & 27.6 & NS \\
\hline
\end{tabular}

Figures 


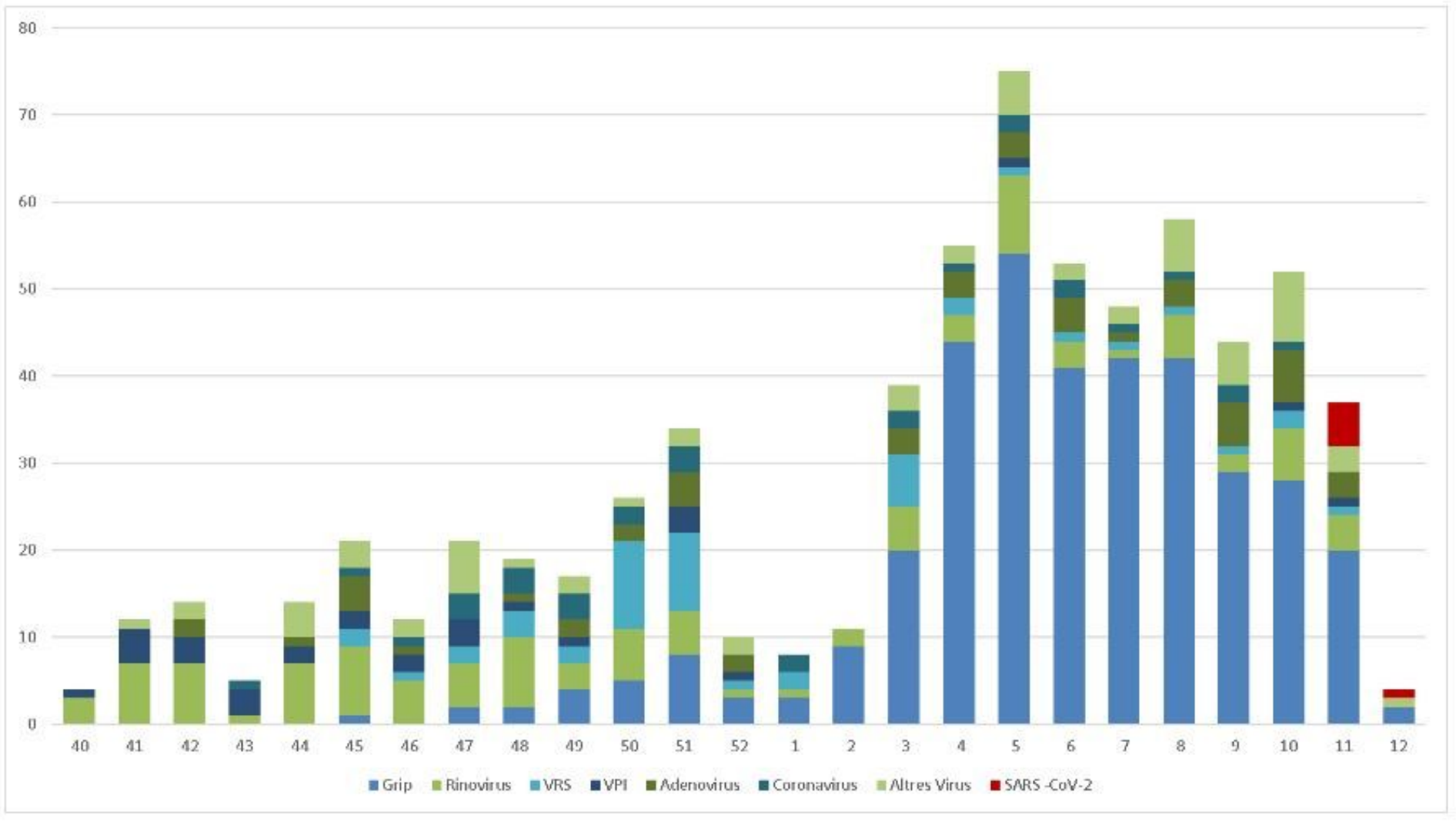

Figure 1

Respiratory virus in the population during winter season. Catalonia, October 2019-April 2020

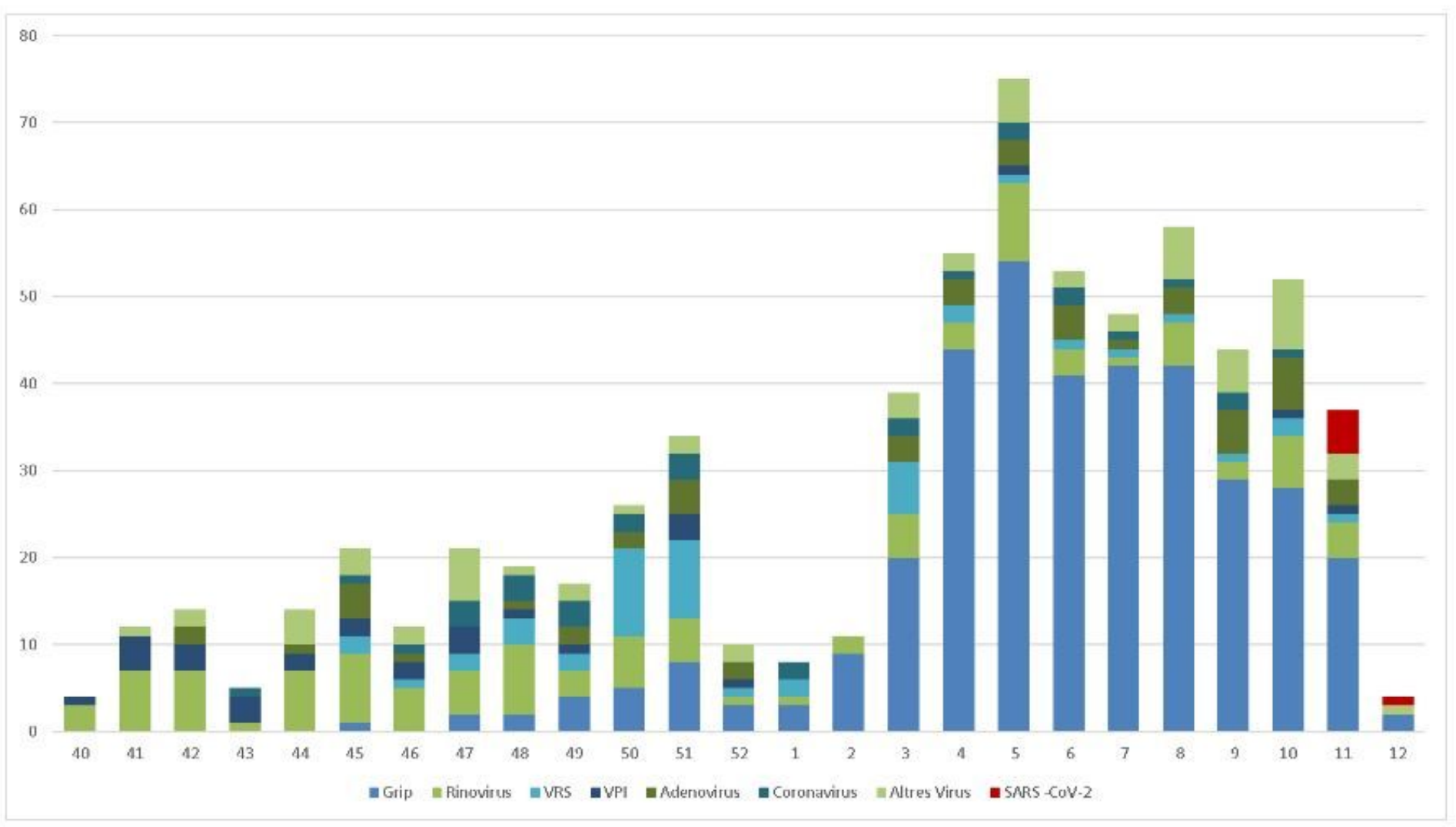




\section{Figure 1}

Respiratory virus in the population during winter season. Catalonia, October 2019-April 2020 